\title{
Assessing the livelihood of slum ewellers in Dhaka city
}

\author{
M. S. Alamgir, M. A. Jabbar ${ }^{1}$ and M. S. Islam ${ }^{2}$ \\ Department of Agricultural Economics, Sylhet Agricultural University, Sylhet, ${ }^{1}$ Department of Agricultural Finance and \\ ${ }^{2}$ Department of Agricultural Economics, Bangladesh Agricultural University, Mymensingh-2202, Bangladesh
}

\begin{abstract}
The present study was an attempt to determine the factors affecting the livelihood of the socioeconomic improvement of migrants and to analyze the causes of rural-urban migration in slum areas. Slum areas have no available formal education facilities and slum people were found to be engaged in rickshaw pulling, day labourer, petty business, small job services etc. Analysis showed that migration and taking in micro credit were beneficial for the slum dwellers. Receiving and utilizing micro credit income level, consumption, expenditure and socio-economic status of the slum dwellers improved to some extent. Due to participation of slum dwellers in NGOs, their economic, social and decision making improved substantially. Credit disbursement through NGOs with integrated approach could bring positive changes in the life of poor slum women as well as their community. Findings showed that Fifty six per cent people migrated to Dhaka city for economic reason. Factors of migration had a significant contribution of rural urban migration and also significant livelihood improvement has taken place due to micro credit. At the individual level, the women were benefited in terms of mobility and skill, self confidence, widening of interests, access to financial services, build own savings, competence in public affairs and status at home and in the community that lead a better awareness for enhancing women's empowerment. However, there is a need for proper training for sustainable result in the long run.
\end{abstract}

Keywords: Migration, Livelihood, Micro credit

\section{Introduction}

The importance of urban development concerns of worldwide recognition and acceptance, especially in the context of the developing world. World Bank, Asian Development Bank and other international lending and funding organizations are also giving a lot of emphasis to address the issue of urban poverty, which is more prevalent in the slums. Many people of urban areas are in search of jobs and continue to live in a very unhealthy environment without proper shelter, drinking water and sewerage facilities. Some of the slums are located near the waste dumping sites and many of them are near the railway lines. The poor economic condition is also due to the unavailability of job opportunities in the urban areas. Urban poverty in fact emerges as a complex phenomenon than rural poverty, with aspects of environmental degradation, inadequate planning and management of urban resources, unemployment, mismanaged investments in technology as well as insufficient mobilization of communities. Equally notable is the mental and psychosocial factors which divide between the poor and the not so poor, ridden with misconceptions and a lack of understanding of what comprises poverty or vulnerability. At the turn of the new millennium, Bangladesh's urban population is about 16 million which work out to about a third of the population. This figure is projected to grow at the rate of about 3 per cent per year in the next decade. By the year 2025, 50 per cent of the populations of Bangladesh are expected to be living in urban areas. Although urbanization is often associated with increasing national production and high per capita GDP, poverty remains a persistent feature of the urban life, both in terms of income and living conditions (Roy and Sarker, 2006).

Micro credit programs are currently being promoted as a key strategy for poverty alleviation. The savings and credit programs are very common in the rural areas of the developing world. At present the attention is also focused on the urban poor like slum dwellers for their development. Micro credit can bring immediate and tangible benefits to the poorest members of the society while also promoting social change and empowerment. The goal of micro credit is to improve the lives of the poor by helping them to help themselves. It is also expected that micro credit plays a significant role in the urban poverty alleviation and the improvement of the living conditions of the poor people living in urban areas.

Bangladesh is one of the most populated countries of the world. The total population of Bangladesh is 142 million with a growth rate 1.43 per cent (BER, 2007). In a survey carried out by the United Nations, Dhaka is identified as a mega city and it would be eighth populous city of the world. Dhaka is now experiencing a period of cramped population growth and migrants are mainly responsible for this high growth rate. In 2007 the population of Dhaka city is more than 10 million and a report expects it to swell 16 million by the year 2010 and 25 million by the year 2025 (Democracy Watch, 2002). This influx of people in capital city has forced many low-income groups to live in slums. About 60 per cent of the 
populations in Dhaka city are migrants where more than 65 per cent of the people live in slum areas. The physical condition of slums is characterized by high density living, improper utilization of public goods, lack of basic amenities, unhygienic and polluted environment, poor literacy rate, unemployment, crime, social, moral and psychological degradation and poor health. Slums mainly provide informal labor market, characterized by low wage, insecurity and uncertainty of working hour. Almost all the newcomers to the city join the informal sectors. The main sectors are garment industry, rickshaw pulling, street vending, construction works and small business. They are living in such houses where ventilation, drinking water, electricity and sewerage facilities are absent and they create new problems like unemployment, underemployment, high incidence of crime, proliferation of shanty towns, sub-standard housing, transportation, pollution and service supply problems. Some government organizations and NGOs have been working for decades to improve the slum dwellers' standard of living, but as a whole the results are minimal. An attempt has been made to evaluate the factors influencing migration to urban areas and the role of NGOs credit on the socioeconomic development of slum dwellers.

\section{Materials and Methods}

Keeping the objectives in view the data were collected from slums through field survey. Out of many slums in Dhaka city, three slums named Agargaon Radio Office (North-east Side), Karail, and Khilgaon Bagicha slums were purposively selected to collect required data depending upon the size of the slums with a large population, the length of time of the NGO operation in the slums and largest number of NGO members. From these slums in total 90 slum dwellers who migrated from rural areas and involved in micro-credit were selected. Data were collected through personal interviews with the selected slum dwellers by field survey. The data were collected during the period from August to December, 2006. The collected data were analyzed using specially regression analysis and logit model to determine the potential variables affecting migration.

\section{Result and Discussion}

\section{Socioeconomic Profile of the Slum Dwellers}

The overall socioeconomic conditions of slum dwellers are not good at all. Socioeconomic characteristics such as age, education level, male-female ratio, family size, occupational status, annual income etc were considered.

Age of the slum dwellers was classified into three categories such as less than 15 years, 16-55 years, and above 55 years. The 16-55 years is considered as working group. The household members aged between 16-55 years constituted the highest 57 per cent which reveals that working age group dominated the slum dwellers.

Education is considered as an important factor of the socioeconomic characteristics of the household. In slum areas there are no available formal education facilities for slum dwellers. Maximum slum dwellers are out of education but some NGOs and organization try to bring them in informal education. Some respondents got educational facilities when he stayed in villages. Female were less educated than the male in the study area. More than 7 per cent of the male members had secondary level of education while female with secondary level of education constituted higher (7 per cent) than male members. Maximum population of slum areas like 58 per cent of male member and 54 per cent of female members were illiterate.

It is known that the average size of the family/household of the slum dwellers was 4.78 that were slightly lower than that of the national family size of 4.92 (BBS, 2004). It further shows that household of the slum dweller respondents consisted of 39 per cent of earning members and 61 per cent of dependent persons. The dependency ratio was found to be 2.59 indicating that there were about 3 dependent persons in the household per earning member.

Occupation of different earning members in households is one of the determining factors of household status. Occupational status of the household members is shown in Table 1. In case of main occupation most of the household heads were engaged in informal services like petty business (Footpath vendor, hawker etc.) day labor, rickshaw pulling, labor in construction buildings small job service etc, where 25 per cent had rickshaw pulling and 17 per cent had petty business while 83 per cent spouse served as a housewife in the respective family. A major portion of slum dwellers earning member has subsidiary 
occupation such as petty business, day labor, rickshaw pulling, tailoring, cooking food for sale for floating man, hawker, and garments worker and others. In subsidiary occupation others (Housewife, maid servant, cook, beggar, tailoring, unemployed etc) occupied the highest place for household head, spouse and the other members of the family.

Table 1. Livelihood status of the slum dwellers

\begin{tabular}{|l|c|c|c|c|}
\hline Names of the livelihood & $\begin{array}{c}\text { No. of } \\
\text { household head }\end{array}$ & $\begin{array}{c}\text { No. of } \\
\text { spouse }\end{array}$ & Others & All \\
\hline Main occupation & $15(17)$ & 0 & $6(10)$ & $21(13)$ \\
\hline Petty business & $21(23)$ & 0 & $11(19)$ & $32(19)$ \\
\hline Day laborer & $23(25)$ & 0 & $14(24)$ & $37(22)$ \\
\hline Rickshaw pulling & $14(16)$ & $3(17)$ & $8(14)$ & $25(15)$ \\
\hline Small job service & $17(19)$ & $15(83)$ & $19(33)$ & $51(31)$ \\
\hline Others* & $90(100)$ & $18(100)$ & $58(100)$ & $166(100)$ \\
\hline Total & $10(11)$ & $2(7)$ & $3(6)$ & $15(9)$ \\
\hline Subsidiary & $15(17)$ & 0 & $10(21)$ & $25(15)$ \\
\hline Petty business & $19(21)$ & 0 & $14(30)$ & $33(20)$ \\
\hline Laborer & $5(6)$ & $3(10)$ & $7(15)$ & $15(9)$ \\
\hline Rickshaw pulling & $41(45)$ & $24(83)$ & $13(28)$ & $78(47)$ \\
\hline Small job service & $90(100)$ & $29(100)$ & $47(100)$ & $166(100)$ \\
\hline Others*
\end{tabular}

Figures in the parentheses indicate percentages of total

Others $^{*}=$ Housewife, maid servant, cook, beggar, tailoring, unemployed etc.

\section{Changes in Household Income from Livelihood Heads and Expenditure}

Income is another important livelihood capital, which determines the household status largely. Household income of the slum dwellers comprises different sources. Table 2 shows the current annual average income of the slum dwellers household from different sources such as petty business, day labor, rickshaw pulling, small job service, and others. The overall average annual income of the households was to be Taka.36528. Table 5 reveals that highest average annual income earned the small job services.

Table 2. Annual average incomes of the slum dwellers

\begin{tabular}{|l|c|}
\hline \multicolumn{1}{|c|}{ Livelihood heads } & Average amount (TK) \\
\hline Petty Business & 35500 \\
\hline Day labor & 38200 \\
\hline Rickshaw pulling & 38540 \\
\hline Small job service & 45000 \\
\hline Others* & 25400 \\
\hline Mean & 36528 \\
\hline SD & 7133 \\
\hline
\end{tabular}

Others $^{\star}=$ Housewife, maid servant, cook, beggar, tailoring, unemployed etc.

\section{Income and Consumption Patterns of Slum Dwellers}

After having been the group members of NGOs, the respondents were engaged in different economic activities under NGOs credit program. Total income was estimated by summing up of income generated from selected enterprises and other sources. Per person per day income was calculated, first by converting per annum income to per day and finally dividing by average family size. This income per person per day was converted in dollar by dividing with Taka 68. Table 3 shows the income poverty status of the respondents. According to the World Bank definition poverty line was estimated at an income of US \$ 1 per person per day. After involvement in credit program, per person per day income was the highest in dollar 0.62 for small job service households followed by $0.38,0.38,0.30$ and 0.27 dollar for petty business, rickshaw pulling, daily labor and others households respectively. 
Table 3. Income poverty status of the slum dwellers in Dhaka city

\begin{tabular}{|c|c|c|c|c|c|c|c|c|}
\hline \multirow[t]{3}{*}{ Occupation } & \multirow{3}{*}{$\begin{array}{c}\text { Av. } \\
\text { family } \\
\text { size }\end{array}$} & \multirow{2}{*}{\multicolumn{2}{|c|}{$\begin{array}{c}\text { Total annual income } \\
\text { (Tk.) }\end{array}$}} & \multicolumn{4}{|c|}{ Income per person per day } & \multirow{3}{*}{$\begin{array}{c}\text { Change } \\
(\$)\end{array}$} \\
\hline & & & & \multicolumn{2}{|c|}{ Taka } & \multicolumn{2}{|c|}{ Dollar (\$) } & \\
\hline & & Before & After & Before & After & Before & After & \\
\hline Petty business & 5.38 & 31860 & 50900 & 16.22 & 25.92 & 0.23 & 0.38 & 0.15 \\
\hline Day labor & 5.67 & 34005 & 42720 & 16.43 & 20.64 & 0.24 & 0.30 & 0.06 \\
\hline Rickshaw pulling & 4.60 & 31260 & 43780 & 18.62 & 26.07 & 0.27 & 0.38 & 0.11 \\
\hline Small job service & 3.68 & 47770 & 57350 & 35.56 & 42.69 & 0.52 & 0.62 & 0.10 \\
\hline Others* & 4.29 & 21260 & 29680 & 13.58 & 18.95 & 0.19 & 0.27 & 0.08 \\
\hline All average & 4.72 & 33231 & 44886 & 19.27 & 26.03 & 0.28 & 0.38 & 0.10 \\
\hline
\end{tabular}

Others $^{*}=$ Cook, Maidservant, Tailoring, Mason, Garments worker

The overall average income per person per day was 0.28 dollar before and 0.38 dollar after their involvement in NGOs and the net change was 0.10 dollar but the highest net change in petty business which is 0.15 dollar.

Table 4 shows that on an average the expenditure increased by 73.22 per cent on education, on family consumption 59.27 per cent, 35.36 per cent on household asset building, 21.16 per cent on clothing, 14.57 per cent on medical treatment and 13.17 per cent on housing in the study areas. The percentage increase in expenditure was the maximum (73.22 per cent) for education and minimum (13.17 per cent) for housing. A close relationship with consumption and increase in income was found and respondents have spent more money for household affairs after involved in the micro credit program.

Table 4. Changes of expenditure of slum dwellers

\begin{tabular}{|l|c|c|c|c|}
\hline \multirow{2}{*}{ Items } & \multicolumn{2}{|c|}{ Annual average cost (Tk) } & \multirow{2}{*}{$\begin{array}{c}\text { Annual net } \\
\text { change (Tk.) }\end{array}$} & \% Change \\
\cline { 2 - 3 } & Before & After & 13038 & 35.36 \\
\hline Household asset building & 36870 & 49908 & 11811 & 59.27 \\
\hline Family consumption & 19925 & 31736 & 453 & 21.16 \\
\hline Clothing & 2140 & 2593 & 168 & 13.17 \\
\hline Housing & 1275 & 1443 & 156 & 14.57 \\
\hline Medical treatment & 1070 & 1226 & 372 & 73.22 \\
\hline Education & 508 & 880 & 4333 & 42.07 \\
\hline All average & 10298 & 14631 & & \\
\hline
\end{tabular}

\section{Economic and Social Status Index}

Table 5. Economic status index of the respondents

\begin{tabular}{|c|c|c|c|c|}
\hline $\begin{array}{c}\text { Types of economic } \\
\text { status }\end{array}$ & Weight/Score & $\begin{array}{c}\text { No. of } \\
\text { respondents }\end{array}$ & $\begin{array}{c}\text { Percentage of } \\
\text { respondent }\end{array}$ & $\begin{array}{c}\text { Index of economic } \\
\text { status }\end{array}$ \\
\hline No change & 0 & 1 & 22 & \multirow{6}{*}{$51.51 \%$} \\
\hline Little change & 1 & 9 & 36 & \\
\hline Moderate change & 2 & 13 & 42 & \\
\hline High change & 3 & 7 & 0 & \\
\hline Very high change & 4 & 3 & 0 & \\
\hline Total & & 33 & 100 & \\
\hline
\end{tabular}

$$
\begin{aligned}
\text { Economic Status Index }(\mathrm{ESI}) & =\left(\sum \mathbf{W}_{\mathrm{i}} \mathbf{f}_{\mathrm{i}} / \mathbf{M}\right) \mathbf{X 1 0 0} \\
& =\{(0.1+1.9+2.13+3.7+4.3) /(33.4)\} \times 100 \\
& =52
\end{aligned}
$$

Table 5 shows Economic Status Index of economic impacts of NGOs on selected indicators was 51 per cent. It is evident that as a result of the participation of slum dwellers in NGOs, their economic condition improved substantially. 
Micro credit program has its positive impact on decision making power of women. The decision making power in the household was one of the strong determinants of a woman's status as in home and at society. Borrowers self esteem and self-confidence increased greatly through micro credit. During the group discussion some women shared how they felt confident to decide on whether to take children to school. This was made possible by the fact that they had become productive in their own right, contributing to family income and was entitled to participate in such decision making.

Table 6. Social status index of the respondents

\begin{tabular}{|c|c|c|c|c|}
\hline Types of Social status & Weight & $\begin{array}{c}\text { No. of } \\
\text { respondents }\end{array}$ & $\begin{array}{l}\text { Percentage of } \\
\text { respondents }\end{array}$ & $\begin{array}{c}\text { Index of economic } \\
\text { status }\end{array}$ \\
\hline No change & 0 & 4 & 12 & \multirow{6}{*}{44} \\
\hline Little change & 1 & 8 & 24 & \\
\hline Moderate change & 2 & 15 & 46 & \\
\hline High change & 3 & 4 & 12 & \\
\hline Very high change & 4 & 2 & 6 & \\
\hline Total & & 33 & 100 & \\
\hline
\end{tabular}

Social Status Index $(\mathrm{SSI})=\left(\Sigma \mathrm{w}_{\mathrm{i}} \mathrm{f}_{\mathrm{i}} / \mathrm{M}\right) \mathrm{X100}$

$$
\begin{aligned}
& =\{(0.4+1.8+2.15+3.4+4.2) /(33.4)\} \times 100 \\
& =44
\end{aligned}
$$

Social Status Index of social impacts of NGOs on selected indicators was 44 per cent is shown in Table 6. It is evident that as a result of the participation of slum dwellers in NGOs, their social condition improved substantially.

In cases of difficult partners and spouses, many women from the slum indicated that their courage to continue in decision-making stemmed from a sense of community support from other members. Because women worked a group, they developed friendship and sisterhood relation with each other and solicit help and support when in difficult situations was present in their lives.

The research result illustrated women's role in decision making was stronger both in household affairs and in loan aspects. The women respondents of NGO said that these days they could manage in discussing their interest in participating different household (food, clothing, education of children) and loan aspects (taking loan, using loan, and repayment of loan) with their husband jointly.

Although during the discussion in most cases the husband led the conversation and women members were very happy in joint negotiation with their husbands. 55\% of respondents of NGO were fully able to participate jointly with their husband in the process of decision making in taking loans and using them and $61 \%$ respondents said in the decision on household affairs they can think and share their thought which is shown in table 7.

Generally the women belongs to the scheduled tribe are more free from social norms, and traditional gender ideology and are able to take their decisions of their own in most cases.

Table 7. Decision making status of the respondents

\begin{tabular}{|l|c|c|}
\hline Decision in loan aspect & No. of respondents & percentage \\
\hline Husband only & 12 & 36 \\
\hline Jointly & 18 & 55 \\
\hline Respondent only & 3 & 9 \\
\hline Total & 33 & 100 \\
\hline Decision in household affairs & \multicolumn{2}{|c|}{} \\
\hline Husband only & 8 & 24 \\
\hline Jointly & 20 & 61 \\
\hline Respondent only & 5 & 15 \\
\hline Total & 33 & 100 \\
\hline
\end{tabular}




\section{Specification and measurement of variable factors}

Various functional models can be used in multiple regression analysis. Functional analysis is used to reveal the relationship between dependent variables and set of explanatory variables (Gujarati, 2003 and Koutsoyinnis, 2002).To determine the effects of explanatory variables, linear model was used in this study.

This study finds out a number of factors from field survey in the study areas is shown in Table 8. The factors encouraged the poor people to migrant to the city from rural areas. Migration is the dependent variable and the following factors which influenced to migration are independent variables. The multiple regression equation used is of the following form.

$\mathrm{Y}=\mathrm{a}+\mathrm{b}_{1} \mathrm{X}_{2}+\mathrm{b}_{2} \mathrm{X}_{4}+\mathrm{b}_{3} \mathrm{X}_{6}+\mathrm{b}_{4} \mathrm{X}_{17}+\mathrm{b}_{5} \mathrm{X}_{19}+\mathrm{b}_{6} \mathrm{X}_{24}+\mathrm{ei}$

Here, $Y=$ Dependent variable (Migration)

$b_{1} \ldots \ldots \ldots . . . b_{6}=$ Regression coefficient of respective variables

$\mathrm{X}_{2}, \mathrm{X}_{4}, \mathrm{X}_{6}, \mathrm{X}_{17}, \mathrm{X}_{19}, \mathrm{X}_{24}=$ Independent variables

Table 8. Factors of migration of slum dwellers from rural to urban areas

\begin{tabular}{|c|c|}
\hline $\mathrm{X}_{1:}$ Failure to repay NGO loan & $\mathrm{X}_{14:}$ Deprived of hereditary rights \\
\hline $\mathrm{X}_{2:}$ Searching for work & $\mathrm{X}_{15:}$ Oppressed \\
\hline $\mathrm{X}_{3}$ : Escape conviction & $X_{16:}$ Loss/death of guardian \\
\hline $\mathrm{X}_{4:}$ Better livelihood & $X_{17:}$ Loss of income sources \\
\hline $\mathrm{X}_{5}:$ Homelessness & $\mathrm{X}_{18:}$ Escape village enemy \\
\hline $\mathrm{X}_{6:}$ Landlessness & $\mathrm{X}_{19:}$ Easy access to informal sector \\
\hline $\mathrm{X}_{7:}$ Threatened by opposition & $\mathrm{X}_{20}$ : Easy access to slum areas \\
\hline $\mathrm{X}_{8:}$ River erosion & $\mathrm{X}_{21:}$ Positive information about the city (garment factory jobs, etc) \\
\hline $\mathrm{X}_{9}$ : Natural disaster & $\mathrm{X}_{22:}$ Higher income probability \\
\hline $\mathrm{X}_{10:}$ Conviction/got-up cases & $\mathrm{X}_{23:}$ Better service facilities \\
\hline $\mathrm{X}_{11:}$ Marital factors (divorce, newly & $\mathrm{X}_{24:}$ Relatives/joining families \\
\hline married, etc) & $\mathrm{X}_{25:}$ Fast life in city \\
\hline$X_{12:}$ Loosened family bondage & $X_{26:}$ Do not like village/no electricity \\
\hline $\mathrm{X}_{13:}$ Too many family members & \\
\hline
\end{tabular}

Determinants with comparatively higher frequencies were included in this model. The following determinants are highly correlated with the dependent variable migration, and help minimize the number of factors that show potential determinants. In Table 9 reveals that the following factors entered into the final model which are $\mathrm{X}_{2}$ : searching for work; $\mathrm{X}_{4}$ : better livelihood; $\mathrm{X}_{6}$ : landlessness; $\mathrm{X}_{17}$ : loss of income sources; $\mathrm{X}_{19}$ : easy access to informal sector; $\mathrm{X}_{24}$ : joining relatives/families

Table 9. Regression coefficients of factors of migration

\begin{tabular}{|l|c|c|}
\hline \multicolumn{1}{|c|}{ Variables } & Regression coefficients & Significance $^{*}$ \\
\hline Constant & -898.032 & 0.005 \\
\hline $\mathrm{X}_{2}$ Searching for work & 1.092 & 0.002 \\
\hline $\mathrm{X}_{4}$ Better livelihood (extreme poverty) & 3.557 & 0.004 \\
\hline $\mathrm{X}_{6}$ Landlessness & 2.775 & 0.008 \\
\hline $\mathrm{X}_{17}$ Loss of income sources & 3.005 & 1.04 \\
\hline $\mathrm{X}_{19}$ Easy access to informal sector & 2.085 & 0.007 \\
\hline $\mathrm{X}_{24}$ Joining relatives/families & 1.008 & \\
\hline Value of $\mathrm{R}^{2}$ & \multicolumn{2}{|c|}{0.77} \\
\hline
\end{tabular}

*Significant at $5 \%$ level 


\section{Regression line}

$Y=-898.032+1.092^{\star} X_{2}+3.557^{\star} X_{4}+2.775^{\star} X_{6}+3.005^{\star} X_{17}+2.085^{\star} X_{19}+1.008^{\star} X_{24}$

The R2=0.778 shows the usefulness of this model in analyzing the determinants that influences the migration process potentially, and hence, 78 per cent variation of rural-urban migration is explained by six factors; searching of work, better livelihood, landlessness, loss of income sources, easy access to informal sector, and joining relatives/ families.

Alamgir et al.

Regression coefficient of the searching for work was found to be $b_{1}=1.092$ and statistically significant at $5 \%$ level. It is logical that searching for work influence to the people to migrate from rural to urban areas.

Regression coefficient of better livelihood was $b_{2}=3.557$ which is statistically significant at $5 \%$ level and influence to rural-urban migration.

The coefficient of the landlessness was to be $b_{3}=2.775$ which indicate that landlessness contributes significantly towards migrate in Dhaka city.

In the regression analysis, loss of income of the respondents significantly affects the rural-urban migration. The regression coefficient was $b_{4}=3.005$ which was significant at $5 \%$ level of confidence. It provides sufficient evidence to say that respondents' loss of income had significantly influenced the migration.

Regression coefficient of easy access to informal sector was found to be $b_{5}=2.085$ which is significant at $5 \%$ level and coefficient of joining relatives was $b_{6}=1.008$. It shows that joining relatives had a significant contribution to rural-urban migration.

\section{Factors Affecting the Likelihood of the Socioeconomic Improvement}

In order to explain the likelihood of improvement in the overall Socioeconomic condition, the following factors were used to estimate a logistic regression function. The results are presented in table 10 . The explanatory variables used in the regression were dichotomous where a score of 1 was assigned to the positive response and a score of 0 assigned to negative outcome (indicating that no improvement took place).

Among the ten independent variables, it was found that eight variables had significant influence on the dichotomous dependent variables. In case of logistic regression the convention is to interpret the odd ratios not the co-efficient. Odd ratios were computed (computer output provide the odd ratios directly) by taking the anti log of the co-efficient.

Table 10. Result of logistic regression on the socioeconomic wellbeing

\begin{tabular}{|l|c|c|c|}
\hline \multicolumn{1}{|c|}{ Variables } & Co-efficient & S.E. & Odd ratio \\
\hline Constant & -7.52 & 2.68 & 0.001 \\
\hline Income & $0.002^{\star}$ & 0.001 & 1.002 \\
\hline Consumption & $1.786^{\star}$ & 0.788 & 5.963 \\
\hline Children education & $1.936^{\star *}$ & 0.796 & 6.928 \\
\hline House hold assets & 1.55 & .792 & 3.175 \\
\hline Improving housing condition & 1.23 & 0.89 & 3.430 \\
\hline Decision making ability & $1.500^{\star *}$ & 0.764 & 4.484 \\
\hline Knowledge and Skills & $2.051^{\star}$ & 0.775 & 7.778 \\
\hline Informal groupings & $1.690^{\star \star}$ & 0.859 & 5.422 \\
\hline Women empowerment & $1.851^{\star}$ & 0.734 & 6.364 \\
\hline Participation in social activity & $01.314^{\star \star}$ & 0.593 & 3.721 \\
\hline Likelihood ratio & \multicolumn{3}{|l|}{} \\
\hline
\end{tabular}

Note: a) *Significant at $5 \%$ level

b) $* \star$ Significant at $1 \%$ level

Table 10 shows that Incase of income odd ratio was 1.002 suggesting that probability of increase income 1.002 times for slum dwellers after micro credit involvement. 
Incase of consumption the odd ratio was 5.963 meaning that probability of consumption increases appears to be 5.963 times for slum dwellers after micro credit involvement.

Incase of children education the odd ratio was 6.928 meaning that probability of children education to improve livelihood was 6.928 times more for slum dwellers after micro credit involvement.

Improvement in decision making ability is a significant factor influencing the livelihood. The corresponding odd ratio was 4.484 which indicate the decision making ability of slum dwellers increased by 4.484 times more after micro credit involvement.

380

Assessing the livelihood of slum ewellers in Dhaka city

Incase of improving knowledge and skills the odd ratio was 7.778 meaning that probability of improvement appears to be 7.778 times more for slum dwellers after micro credit involvement.

Improvement in informal groupings is a significant factor influencing the livelihood. The corresponding odd ratio was 5.422 which indicate the informal groupings of slum dwellers increased 5.422 times more after micro credit involvement

Incase of women empowerment the odd ratio was 6.364 meaning that probability of women empowerment to improve livelihood was 6.364 times more for slum dwellers after micro credit involvement

Incase of participation in social activity the odd ratio was 3.721. This also suggests that the slum dwellers whose participation increased probability 3.721 times more after micro credit involvement

\section{Conclusion and Recommendation}

Rural-urban migration is not only an integral part of economic development but also a major factor of social change. The poor landless, flood affected, less educated, and illiterate people migrate to urban areas mainly for better job opportunities. Various non-governmental organizations are actively perform their credit related program in the slum areas for improving the livelihood pattern of slum dwellers and also help to create income generating activities of the urban poor especially for slum dwellers in the urban areas of Bangladesh.

Micro credit do increased income and cash saving for the slum dwellers and even they are able to posses more assets for their house. After involvement of micro credit slum dwellers had increased economicsecurity and reduced dependency on money lenders. The slum dwellers were encouraged to join the evacuation rally, anti liquor campaign and participate in different activities.

It should provide trained teacher and appropriate teaching aids suitable for the slum dwellers education program and the training programs on leadership, management of accounts, innovative businesses and other skill development should be conducted on a regular basis. Open handicraft outlets, export to other countries and maintaining the quality of the products which is produced by slum dwellers. This will directly help the slum people to have an assured income for their self independence and empowerment. NGO can negotiate with the local banks to provide some loan, it will help the poor slum dwellers greatly for better business and regular income for their survival and sustainability of the economic condition. All the beneficiaries of slums were socially empowered by all the indicators of empowerment. Though it seems women have gained self-confidence and self-esteem high prevalence of incidences of violence at least makes clearer that empowerment has not been fully achieved. Thus the findings of the study imply that policy makers should take all possible steps and measures to improve the livelihood condition of slum dwellers in Dhaka city.

\section{References}

BBS 2004. Statistics Division, Ministry of planning, Government of the People's Republic of Bangladesh, Dhaka.

BER 2007. Bangladesh economic Review, Economic Adviser's Wing, Finance Division, Ministry of Finance, Government of the People's Republic of Bangladesh, Dhaka.

Democracy Watch 2002. An Assessment on the Uprooted Slum Dwellers of Dhaka City.

Gujarati D.N. 2003. Basic Econometrics. Fourth Edition (International Edition), Published by McGraw-Hill//rwin, New York, NY, 10020 
Koutsoyiannis, A. 2002. Theory of Econometrics, An Introductory Expansion of Econometric Methods, Second Edition Published by Macmillan Education Ltd. Houndmills, Basingstoke, Hampshire RG212XS and London.

Roy, M. K. and Sarker, G.C. 2006. Rural and urban Migration: The Role of Secondary Cities. Report published in the daily Bangladesh observer, p.4 Dated on 16 April. 